\title{
ReSEARChArticle
}

\section{Evaluation of growth parameters and physiological basis of yield in summer soybean genotypes}

\author{
S.M. RALEBHAT, S.K. RANSING AND R.S. WAGH
}

\begin{abstract}
SUMMARY
Pod and seed number are the most important yield components of soybean. Leaf area index (LAI), leaf area duration (LAD) during the reproductive period strongly influence yield components. The study was undertaken with objectives to investigate the significant differences in yield components, physiological traits and growth parameters among genotypes and to examine the dynamics of LAI and LAD during the reproductive period for the high-yielding genotypes. Significant variations were found for LAI, LAD, leaf area, number of branches, plant height and physiological traits. Photosynthetic rate was closely related to stomatal conductance, transpiration and PAR.The rate of photosynthesis is an important physiological parameter which governs the dry matter production and consequently the yield.The genotype KDS-347 (63.60 $\left.\mu \mathrm{mol} \mathrm{m}^{-2} \mathrm{~s}^{-1}\right)$ showed higher photosynthesis rate reflected in high grain yield (2708.33 kg/ha) in these genotypes during summer season. The efficiency of converting biological yield in to economic yield and explained the cause of high grain yield in KDS-347 due to a higher harvest index $(46.78 \%)$. The high yielding genotypes possessed higher rate of photosynthesis indicating the importance of the parameter in determining the productivity.
\end{abstract}

Key Words : Soybean, Yield, LAI, LAD, Photosynthesis

How to cite this article : Ralebhat, S.M., Ransing, S.K. and Wagh, R.S. (2015). Evaluation of growth parameters and physiological basis of yield in summer soybean genotypes. Internat. J. Plant Sci., 10 (1): 7-13.

Article chronicle : Received : 06.06.2013; Revised : 03.11.2014; Accepted : 17.11.2014

\section{MEMBERS OF THE RESEARCH FORUM}

Author to be contacted :

S.M. RALEBHAT, Department of Agricultural Botany, Post Graduate Institute, Mahatma Phule Krishi Vidyapeeth, Rahuri, AHMEDNAGAR (M.S.) INDIA

Email: sangramralebhat068@gmail.com

Address of the Co-authors:

S.K. RANSING, Seed Technology Research Unit, Mahatma Phule Krishi Vidyapeeth, Rahuri, AHMEDNAGAR (M.S.) INDIA

R.S. WAGH, Department of Agricultural Botany, Post Graduate Institute, Mahatma Phule Krishi Vidyapeeth, Rahuri, AHMEDNAGAR (M.S.) INDIA 